\title{
REPRODUCTIVE CHARACTERISTICS OF NORTHERN PIKE, ESOX LUCIUS (ACTINOPTERYGII: ESOCIFORMES: ESOCIDAE), IN THE ANZALI WETLAND, SOUTHWEST CASPIAN SEA
}

\author{
Mehdi MOSLEMI-AQDAM ${ }^{1 *}$, Javid IMANPOUR NAMIN ${ }^{1}$, Masoud SATTARI ${ }^{1}$, Shahram \\ ABDOLMALAKI ${ }^{2}$, Ali BANI ${ }^{3,4}$, and Bastien E.A. ROCHOWSKI ${ }^{5}$ \\ ${ }^{1}$ Fisheries Department, Faculty of Natural Resources, University of Guilan, Sowmeh-sara, Iran \\ ${ }^{2}$ International Sturgeon Research Institute, Agricultural Research, Education and Extension Organization (AREEO), \\ Rasht, Iran \\ ${ }^{3}$ Department of Biology, Faculty of Science, University of Guilan, Rasht, Iran
}

${ }^{4}$ Marine Science Department, Caspian Sea Basin Research Centre, University of Guilan, Rasht, Iran

${ }^{5}$ Mezo Research, Millers Point NSW 2000, Australia

Moslemi-Aqdam M., Imanpour Namin J., Sattari, M., Abdolmalaki Sh., Bani A., Rochowski, B.E.A. 2016.
Reproductive characteristics of northern pike, Esox lucius (Actinopterygii: Esociformes: Esocidae), in
the Anzali Wetland, southwest Caspian Sea. Acta Ichthyol. Piscat. 46 (4): 313-323.

Background. Temporal variability in fish reproductive features is influenced by environmental and spatial variations. Given the wide distribution of northern pike, Esox lucius Linnaeus, 1758, in the northern hemisphere, important reproductive features such as the initiation of the spawning activity are likely to vary with latitudinal gradients. The overall goal of the presently reported study was to answer basic questions regarding the reproductive biology of the pike and to discuss changes in the timing of the onset of spawning activity in relation to geographical locations and the water temperature in the Anzali Wetland compared to higher latitudes.

Materials and methods. Monthly samples (537 specimens in total) were collected from the Anzali Wetland (southwest of the Caspian Sea) from July 2012 through July 2013. Samples were macro- and microscopically examined, and their maturity stages were identified, so that spawning season, monthly distribution of maturity stages, oocytes development, spawning strategy, length at 50\% maturity, and fecundity were estimated.

Results. The gonadosomatic index, oocyte size-frequency distribution, and histological examination suggested a relatively short spawning season, from February through March. The short annual spawning period and the oocyte size-frequency distribution demonstrated that pike is a total spawner with group synchronous oocyte development. The length at $50 \%$ maturity was 28.5 and $33.9 \mathrm{~cm}$ FL for males and females, respectively. Absolute fecundity values ranged from 4423 to 48471 oocytes, with mean ( \pm standard error) of $16481 \pm 2705$ oocytes and the relative fecundity was estimated as $26.9 \pm 1.6$ oocytes per gram of mature female.

Conclusion. The most important findings of this study are: the earlier initiation and relatively shorter duration of the reproductive activities of pike in the south Caspian region compared to northern geographical regions. The results emphasize the need for specific management strategies based on seasonal measures for pike such as: fish size limits, limitation of catches during the spawning season, limitation of the boat number, and closure of the spawning area during spawning months.

Keywords: Esox lucius, fecundity, group synchronous, length-at-maturity, spawning season

\section{INTRODUCTION}

An organism's life history strategy is defined by ontogenetic and reproductive traits that determine individual lifetime reproductive success (Roff 1992). The knowledge of the reproductive strategy of a species is critical to understand its population dynamics (Jakobsen et al. 2009, Salcedo-Bojorquez and Arreguin-Sanchez
2011, Colmenero et al. 2013) and to provide sound scientific advice for fisheries management (Morgan 2008). Reproductive characteristics such as the degree of synchronicity of oocyte development, the spawning pattern, and the type of fecundity are adaptations to maximise the probable survival of offspring and vary widely between species (Ewing and Lyle 2009). In highly

" Correspondence: Mehdi Moslemi-Aqdam M.Sc., Fisheries Department, Faculty of Natural Resources, University of Guilan, PO Box 1144, Sowmeh-sara, Iran, phone: +98 2634662114, fax: +98 2634645327, e-mail: (MMA) mehdimoslemiaqdam@gmail.com, (JIN) javidiman@gmail.com, (MS) msattari@guilan.ac.ir, (ShA) abdolmalaki2014@gmail.com, (AB)ali_bani_2000@yahoo.com,(BEAR)b.rochowski@gmail.com. 
fecund species such as teleost fishes, changes in the structure of a population can be defined by reproductive capability (Einum et al. 2003). The variations in reproductive features (e.g., spawning season, fecundity, and maturity) can be caused by biotic and abiotic factors (Thulasitha and Sivashanthini 2013), and affect the reproductive potential of a species (Marshall et al. 1998). Moreover, within a single species' spawning strategy, conspecific variations have been observed in response to environmental fluctuations, which can influence the timing of spawning seasons, fecundity, and length-atmaturity (Silva et al. 2006, Ziegler et al. 2007).

Depending on the season and the geographical region, fish species can exhibit variability in their reproductive characteristics (Bani and Moltschaniwskyj 2008). In temperate fish species, the gonadal activity changes seasonally with considerable investment into reproduction during the spawning season (Wallace and Selman 1981). The initiation and duration of the spawning season may vary among populations distributed in different geographic regions (Brown-Peterson et al. 2001). Such changes may be due to variations in water temperature, day length, nutrients, and physico-chemical parameters of water, which are recognized as parameters that exert predominant influences on the fish reproductive activity, particularly the time of spawning (Glasser et al. 2004, Yamamoto and Shiah 2012). Changes in these parameters vary with latitude, which may be responsible for latitudinal variations in spawning season of some species (Yamamoto and Shiah 2012).

Northern pike, Esox lucius Linnaeus, 1758 (thereafter pike), is a freshwater fish species with a distribution area covering almost the entire northern hemisphere including Asia, Europe, and North America (Craig 1996, Avian et al. 1998, Lappalainen et al. 2008). Pike in Iran is distributed at the southern edge of the species range (Sattari et al. 2002) and the Anzali Wetland has been mentioned as a main habitat for pike in this region (Abdoli and Naderi 1999). Pike is a highly valuable commercial species in the southwest Caspian Sea, and it makes up for the highest percentage of the catch composition in the Anzali Wetland (Moslemi-Aqdam et al. 2014). Popularity and high market price of pike in the region, has resulted in severe exploitation of its stock and the amount of catch has declined dramatically in recent years from $180 \mathrm{t}$ in 2003 to almost $100 \mathrm{t}$ in 2010 (Moslemi-Aqdam et al. 2014).

Although several studies have addressed the reproductive biology of this species (Bregazzi and Kennedy 1980, Treasurer 1990, Avian et al. 1998, Lenhardt and Cakić 2002, Balık et al. 2006, Nilsson 2006, Žiliukienè and Žiliukas 2012, Pagel unpublished*), the majority of them have been in regions of high latitudes (e.g., England, Scotland, Sweden, Germany, and Lithuania). Information on the reproductive biology of pike in lower latitudes is very limited, so that this study adds information on the variability and plasticity of its reproductive traits. The overall aim was to investigate:

Spawning season, pattern of oocyte development, and spawning strategy based on monthly variations of gonadosomatic index, monthly proportions of maturity stages, and the size-distribution of oocyte;

Length at $50 \%$ maturity;

The absolute and relative fecundity and the relations between fork length, body weight, and fecundity.

In addition, changes in the timing of the onset of the spawning activity are discussed in relation to geographical locations and water temperature in this region compared to higher latitudes.

\section{MATERIALS AND METHODS}

Sampling and laboratory processing. Pike were sampled monthly from the Anzali Wetland (37 $22^{\prime}-$ $37^{\circ} 32^{\prime} \mathrm{N}$; $49^{\circ} 15^{\prime}-49^{\circ} 36^{\prime} \mathrm{E}$ ) (Hargalani et al. 2014) in the southwest of the Caspian Sea (Fig. 1) from July 2012 through June 2013, using gill nets (mesh sizes, 18, 23, $32,36,45,55$, and $60 \mathrm{~mm}$ ). The water temperature data throughout the sampling period were provided by the Iranian Department of Environment, Guilan province**. Fish were caught, stored on ice, transported to the Department of Fishery, University of Guilan, and dissected within six $\mathrm{h}$ from capture. For this study, 537 specimens were sexed (male, female, and immature), measured to the nearest $\mathrm{mm}$ for fork length (FL), weighed to the nearest $\mathrm{g}$ for total body weight $\left(W_{\mathrm{T}}\right)$ and gutted weight $\left(W_{\mathrm{E}}\right)$, and $0.001 \mathrm{~g}$ for gonad weight $\left(W_{\mathrm{G}}\right)$ and liver weight $\left(W_{\mathrm{L}}\right)$. The ovaries were macroscopically staged (Table 1) and preserved in Bouin's solution.

Spawning season, reproductive strategy, and histological analysis. The spawning season was estimated by analysing monthly variation of the maturity stages and the changes in the gonadosomatic index:

$$
\mathrm{GSI}=100 W_{\mathrm{G}} \cdot W_{\mathrm{E}}^{-1}
$$

and the hepatosomatic index:

$$
\mathrm{HSI}=100 W_{\mathrm{L}} \cdot W_{\mathrm{E}}^{-1}
$$

where $W_{\mathrm{G}}$ is the gonad weight, $W_{\mathrm{E}}$ is the gutted (eviscerated) weight, and $W_{\mathrm{L}}$ is the liver weight. Since immature specimens were not considered, a total of 152 males and 255 females were used to determine both indices (Fig. 2).

The oocyte development pattern (i.e., synchronous, group synchronous or asynchronous) and type of spawning strategy (i.e., total or serial spawner) were assessed using oocyte size-frequency distributions (West 1990) along with histological examination (Hunter and Macewicz 1985, West 1990). The size frequency distribution of oocytes within the intact ovaries of 10-16 females at each stage of maturity was determined macroscopically. Cross sections, 2-3 $\mathrm{mm}$ thick, were excised from the centre

\footnotetext{
" Pagel T. 2009. Determinants of individual reproductive success in a natural pike (Esox lucius L.) population: a DNA-based parentage assignment approach. Master Thesis, Faculty of Agriculture and Horticulture, Humboldt-University of Berlin, Germany.

${ }^{* *}$ http://gilan.doe.ir.
} 


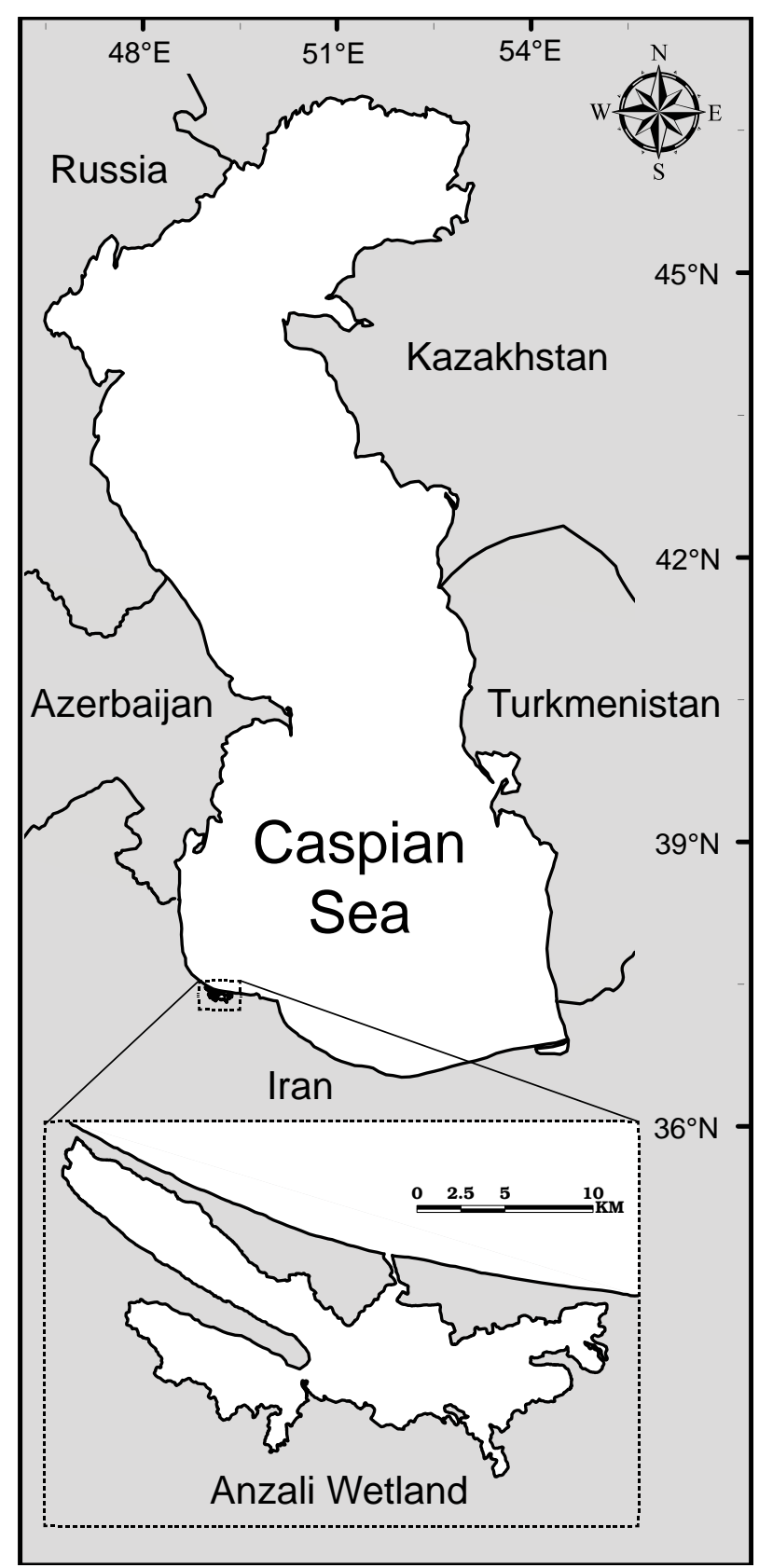

Fig. 1. Map of study area where specimens of pike (Esox lucius) were collected in the Anzali Wetland (southwest Caspian Sea) from July 2012 through June 2013 to examine the reproductive biology of this species

of the right ovary and the oocytes were separated with hypodermic needles. Oocytes were not perfectly spherical in shape, so the mean value of large and small diameters of approximately 300 randomly selected oocytes was calculated after examination under a stereomicroscope with a calibrated ocular micrometer using transmitted light and bright-field illumination. The development stage of each whole-oocyte was determined using the criteria proposed by Davis and West (1993) (Table 1).

Macroscopic staging of the gonad was validated histologically, in which ovaries were staged based on the presence of the most advanced type of oocyte (West 1990). Gonadal segments (median part) from left ovaries preserved for $24 \mathrm{~h}$, were dehydrated in an ethanol series (50\%-96\%), embedded in paraffin, and sectioned at 5 $\mu \mathrm{m}$ (using Opti-Wax tissue processor and Roto Cut 400 microtome, SCILAB, England). The segments were stained with Mayer's haematoxylin and eosin. We assumed there are no significant differences in maturation and oocyte frequency distribution between left and right ovaries: thus, the left ovary was used for histological analysis. A histological classification of oocytes (Table 1) was made based on terminology defined by Yamamoto (1956) and the staging criteria from West (1990) and Brown-Peterson et al. (2011).

Fecundity and length-at-maturity. Absolute fecundity $\left(F_{A}\right)$ was calculated according to the number of oocytes at the beginning of the spawning season (Hunter and Macewicz 1985). Only those fish with undamaged ovaries at the final oocyte maturation (FOM) stage and showing no sign of postovulatory follicles (POF) were considered for $F_{\mathrm{A}}$ estimation (Ganias et al. 2004). Before $F_{\mathrm{A}}$ was estimated, differences in mean oocyte density was tested. Thus, approximately $0.5 \mathrm{~g}$ of ovarian tissue from three sections (anterior, middle and posterior) of both left and right ovaries were taken from 22 females at the final oocyte maturation stage. Because no significant difference was observed between left and right and among three sections of the left ovary (see Results), approximately 0.5 g subsamples were taken from the middle section of the right ovary and the number of oocytes was counted. Then, the absolute fecundity $\left(F_{\mathrm{A}}\right)$ was determined by using the formula provided by Le Cren (1951):

$$
F_{\mathrm{A}}=N_{\mathrm{o}}\left(W_{\mathrm{G}} \cdot W_{\mathrm{s}}^{-1}\right)
$$

where $N_{\mathrm{o}}$ is the number of oocytes in subsample, $W_{\mathrm{G}}$ is the gonad weight, and $W_{\mathrm{s}}$ is the weight of the subsample.

Relative fecundity $\left(F_{\mathrm{R}}\right)$ is the number of oocytes per fish body weight unit $(\mathrm{g})$ :

$$
F_{\mathrm{R}}=F_{\mathrm{A}} \cdot W_{\mathrm{T}}^{-1}
$$

where $W_{\mathrm{T}}$ is the total body weight. $P_{\mathrm{M}}$

Length-at-maturity $\left(L_{50}\right)$ was estimated for each sex based on mature and immature individuals collected before the peak of spawning (Duarte et al. 2001). To avoid classifying immature fishes, only fish collected from December to January were used for this analysis. The proportion of male $(n=96)$ and female $(n=103)$ fish that were reproductively mature during the season in each 1 $\mathrm{cm}$ length class, was calculated and logistic curves (King 1995) were fitted to the data for each sex using a nonlinear least squares procedure:

$$
P_{\mathrm{M}}=1 \cdot\left[1+\exp \left(-a\left(L-L_{\mathrm{m}}\right)\right)\right]^{-1}
$$

where $P_{\mathrm{M}}$ is the proportion of sexually mature individuals as a function of $\mathrm{FL}(L), a$ is the constant with a value which increases with the steepness of the selection curve, and $L_{\mathrm{m}}$ the mean FL at sexual maturity, or the FL corresponding to the proportion of $50 \%$ in reproductive condition. 
Table 1

Macroscopic and microscopic description of the maturity stages in the reproductive cycle of female pike, Esox lucius, collected from the Anzali Wetland (southwest Caspian Sea) from July 2012 through June 2013

\begin{tabular}{|c|c|c|c|c|c|}
\hline $\begin{array}{l}\text { Maturity } \\
\text { stage }\end{array}$ & Category & $N$ & Macroscopic ovary & $\begin{array}{c}\text { Whole-oocyte } \\
\text { analysis }\end{array}$ & Histological analysis \\
\hline I & Immature & 53 & $\begin{array}{l}\text { Very narrow, strip and } \\
\text { flattened-tube shaped, white to } \\
\text { light pink in colour; Oocytes } \\
\text { invisible }\end{array}$ & $\begin{array}{l}\text { Unyolked, } \\
\text { translucent and } \\
\text { spherical; nucleus } \\
\text { invisible }\end{array}$ & $\begin{array}{l}\text { Chromatin nucleolar: Very small } \\
\text { oocytes. Clear, spherical nucleus } \\
\text { surrounded by a thin layer of purple- } \\
\text { stained cytoplasm; No nucleolus } \\
\text { visible }\end{array}$ \\
\hline II & Previtellogenic & 93 & $\begin{array}{l}\text { Ovaries are small, reddish- } \\
\text { pink and translucent. } \\
\text { Vascularization is visible; } \\
\text { Still no noticeable oocytes; } \\
\text { Virgin: Ovary wall thin and } \\
\text { transparent; Recovering: } \\
\text { Ovaries flaccid and ovary wall } \\
\text { thick and opaque. }\end{array}$ & $\begin{array}{l}\text { Unyolked: Spherical } \\
\text { transparent bodies, } \\
\text { nucleus clear and } \\
\text { brownish }\end{array}$ & $\begin{array}{l}\text { Perinucleolar: Oocyte size increases } \\
\text { because of thick cytoplasm around a } \\
\text { light nucleus, containing few to many } \\
\text { peripheral nucleoli; Maximum oocyte } \\
\text { size }=240 \mu \mathrm{m}\end{array}$ \\
\hline III & $\begin{array}{l}\text { Early } \\
\text { vitellogenesis }\end{array}$ & 62 & $\begin{array}{l}\text { Opaque, almost length of } \\
\text { body cavity, increase in width; } \\
\text { Light orange in colour and } \\
\text { blood vessels are prominent; } \\
\text { Oocyte are recognizable }\end{array}$ & $\begin{array}{l}\text { Partially yolked: } \\
\text { Some yolk granules } \\
\text { appear, becoming } \\
\text { darker with } \\
\text { increased size }\end{array}$ & $\begin{array}{l}\text { Cortical alveoli: Appearance of yolk } \\
\text { vesicles in cytoplasm, thick and pink- } \\
\text { stained zona radiata distinguishable at } \\
\text { the end of the stage; Maximum oocyte } \\
\text { size }=400 \mu \mathrm{m}\end{array}$ \\
\hline IV & $\begin{array}{l}\text { Late } \\
\text { vitellogenesis }\end{array}$ & 68 & $\begin{array}{l}\text { Full length of body cavity; } \\
\text { Ova visible }\end{array}$ & $\begin{array}{l}\text { Yolked: Occytes } \\
\text { completely } \\
\text { opaque except for } \\
\text { the translucent } \\
\text { perivitelline border }\end{array}$ & $\begin{array}{l}\text { Vitellogenic yolk: Marked increase } \\
\text { in oocyte size; Maximum oocyte } \\
\text { size }=720 \mu \mathrm{m} \text {; Cytoplasm filled with } \\
\text { yolk granules, oil vesicles and yolk } \\
\text { vesicles; Peripheral nucleolus around } \\
\text { the nuclear membrane; Follicular } \\
\text { layers are detectable }\end{array}$ \\
\hline V & $\begin{array}{l}\text { Final oocyte } \\
\text { maturation }\end{array}$ & 47 & $\begin{array}{l}\text { Ovaries are extremely wide } \\
\text { and occupy all available } \\
\text { space of body cavity before } \\
\text { spawning; Transparent oocytes } \\
\text { visible and expressed with } \\
\text { slight pressure }\end{array}$ & $\begin{array}{l}\text { Nuclear migration: } \\
\text { Most parts of } \\
\text { oocytes become } \\
\text { translucent as yolk } \\
\text { coalesced, except } \\
\text { for the oil droplet }\end{array}$ & $\begin{array}{l}\text { Nuclear migration: Migration of } \\
\text { nucleus to periphery of cytoplasm, } \\
\text { fusion of oil vesicles into an oil } \\
\text { droplet, coalescence of yolk granules } \\
\text { to form uniform plate; Yolk granules } \\
\text { fused into a few plates; Thecal cells } \\
\text { appear like a string; Maximum oocyte } \\
\text { size }=1360 \mu \mathrm{m} \text {; A few perinucleolar } \\
\text { oocytes present }\end{array}$ \\
\hline VI & Spent & 14 & $\begin{array}{l}\text { Ovaries flaccid and bloodshot } \\
\text { with thick wall; Few remnant } \\
\text { oocytes visible. }\end{array}$ & & $\begin{array}{l}\text { Spent: Postovulatory follicles } \\
\text { abundant; Perinucleolar oocytes are } \\
\text { more than previous stage }\end{array}$ \\
\hline
\end{tabular}

$N=$ number of fish; Whole-oocyte analysis was adapted from Davis and West (1993), Histological analysis was adapted from West (1990) and Brown-Peterson et al. (2011).

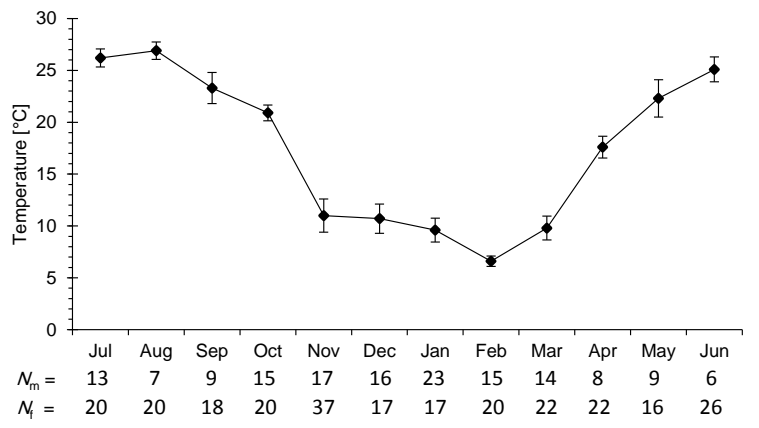

Fig. 2. Mean ( \pm standard error) monthly changes of the water temperature in the Anzali Wetland from July 2012 through June 2013 and the number of male $\left(N_{\mathrm{m}}\right)$ and female $\left(N_{\mathrm{f}}\right)$ pike (Esox lucius) used for estimating gonadosomatic and hepatosomatic indices
Statistical analysis. Prior to the analysis, data were examined for normality and homogeneity of variances using Kolmogorov-Smirnov and Levene tests, respectively. Student's $t$-test was used to test for differences in the number of oocytes per gram between left and right ovary. Analysis of variance (ANOVA) was used to compare the number of oocytes per gram among subsamples taken from the three sections of a single ovary. The use of three sections ensured that analysed subsample represented the entire ovary (Murua and Saborido-Rey 2003). Two-way ANOVA was applied to determine the interaction of gender and month as independent variables with dependent variables of GSI and HSI (log transformed data). The Tukey post hoc result was used to identify significant differences between 
the various mean. Linear, logarithmic, exponential, and power models were fitted to determine what equation best described the relation $F_{\mathrm{A}}$-fork length, $F_{\mathrm{A}}$-body weight, $F_{\mathrm{R}}$-fork length and $F_{\mathrm{R}}$-body weight. Linear relation was selected to describe the relation, based on a visual examination of the residuals and the coefficient of determination $\left(r^{2}\right)$. The highest value of $r^{2}$ with the smallest residuals was considered as the best fitting curve. In order to compare published data, a conversion factor from Bregazzi and Kennedy (1980) was used to convert FL to TL:

$$
\mathrm{TL}=0.94 \cdot \mathrm{FL}^{-1}
$$

Statistical analyses were conducted using SPSS (version 16, Inc., Chicago, IL, USA). Results were considered significant at the $95 \%(P<0.05)$ level.

\section{RESULTS}

Spawning season, gonadal development and reproductive strategy. The FL ranged from 20.5 to $56.6 \mathrm{~cm}$ for males and from 18.3 to $66.1 \mathrm{~cm}$ for females, while the $W_{\mathrm{T}}$ ranged from 56.3 to $1852.3 \mathrm{~g}$ for males and from 52.9 to $2050.3 \mathrm{~g}$ for females. The mean GSI increased, for both sexes, in October $($ males $=1.10$ and females $=1.22$ ) and reached its maximum in January (1.99 and 10.67 for males and females respectively, Fig. 3), while the extent of the increase was noticeably higher in females. Changes in GSI were dependent upon the combination of gender and month (ANOVA; $\left.F_{\text {gender*month }}=4.93, \mathrm{df}=11, P<0.05\right)$. The GSI decreased from February (1.21 and 2.68 for males and females, respectively) and both sexes showed low GSI between April (males $=0.19$ and females $=0.16$ ) and September $($ males $=0.16$ and females $=0.21)$. GSI values indicated that pike, spawned from February through March. Spawning time coincided with the beginning of a slight increase in water temperature in February (Fig. 2).

No significant differences over months were found in HSI values (Fig. 4) between sexes $(P>0.05)$. However, changes in HSI were dependent upon month within both

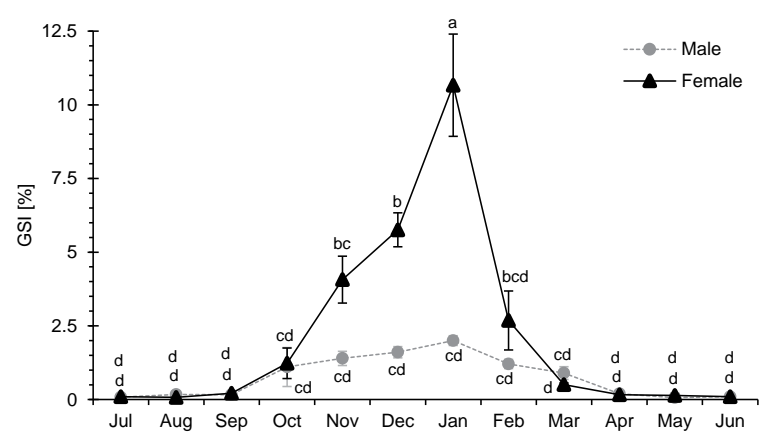

Fig. 3. Monthly changes in the mean gonadosomatic index (GSI) of pike (Esox lucius) collected from the Anzali Wetland (southwest Caspian Sea) from July 2012 through June 2013; Values represent the mean \pm standard error; Means sharing the same letter are not significantly different sexes $\left(\mathrm{ANOVA} ; F_{\text {month }}=3.89, \mathrm{df}=11, P<0.05\right)$. Minimum and maximum HSI values were found in August (0.99) and March (1.98) for males, respectively. In females, the minimum (1.10) and maximum (2.61) HSI values were observed in September and March, respectively.

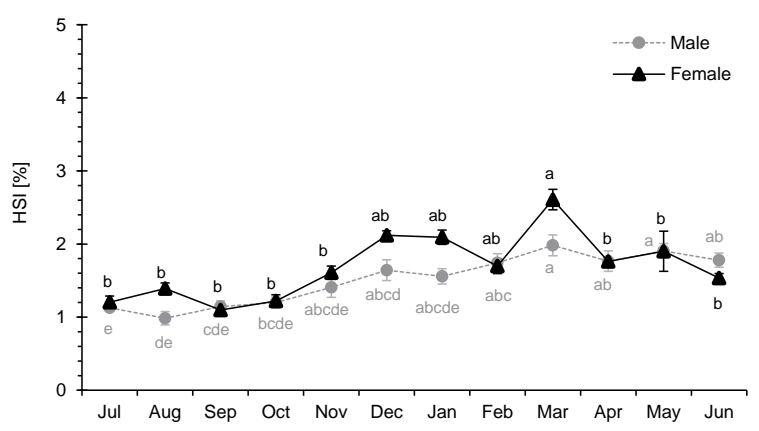

Fig. 4. Monthly changes in the mean hepatosomatic index (HSI) of pike (Esox lucius) collected from the Anzali Wetland (southwest Caspian Sea) from July 2012 through June 2013; Values represent the mean \pm standard error; Means sharing the same letter are not significantly different

The diameter of oocytes was less than $240 \mu \mathrm{m}$ (Fig. 5 ) in the previtellogenic stage (II). Stage II was observed from February to July (Fig. 6) and was the longest stage of oocyte development. In this stage oocytes presented a spherical nucleus with some nucleoli in periphery and a thin cytoplasm surrounding the nucleus (Fig. 7A). In the previtellogenic stage (III), which was present from July through November (Fig. 6), oocyte diameter reached $400 \mu \mathrm{m}$ (Fig. 5) and cortical alveoli oocytes (primary vitellogenesis) were visible in the histological sections (Fig. 7B). Stage IV ovaries (late vitellogenesis) were present from October to December (Fig. 6) when oocytes diameter increased to approximately $720 \mu \mathrm{m}$ (Fig. 5) due to secondary vitellogenesis with endogenous resources and accumulation of yolk vesicles in the oocytes (Fig. 7C). In the final oocyte maturation stage (V), large nucleusmigrated oocytes accompanied by smaller prinucleolar oocytes were apparent (Fig. 7D). In this stage, which was prevailing in December and January and was also observed in February (Fig. 6), the oocyte diameter reached the maximum size of $1360 \mu \mathrm{m}$ (Fig. 5). Finally, spent ovaries (Stage VI) containing postovulatory follicles (POFs) along with some previtellogenic oocytes (Fig. 7E) were present in February and March (Fig. 6).

Fecundity and length-at-maturity. There were no significant differences in the number of oocytes between left and right ovaries $(t=-0.03$; df $=46 ; P>0.05)$ or among three sections of left ovaries (ANOVA; $F=0.009$; $\mathrm{df}=2 ; P>0.05)$. The $F_{\mathrm{A}}$ of 22 females with $31.4-52.8$ $\mathrm{cm}$ FL ranged from 4423 to 48471 , and mean $F_{\mathrm{A}}$ ( \pm standard error) was $16481 \pm 2705.2 . F_{\mathrm{A}}$ and $F_{\mathrm{R}}$ tended to increase linearly with the $W_{\mathrm{T}}$ and FL (Fig. 8), indicating that fecundity is dependent on size and body weight of fish. Non-linear equation showed lower coefficient of 


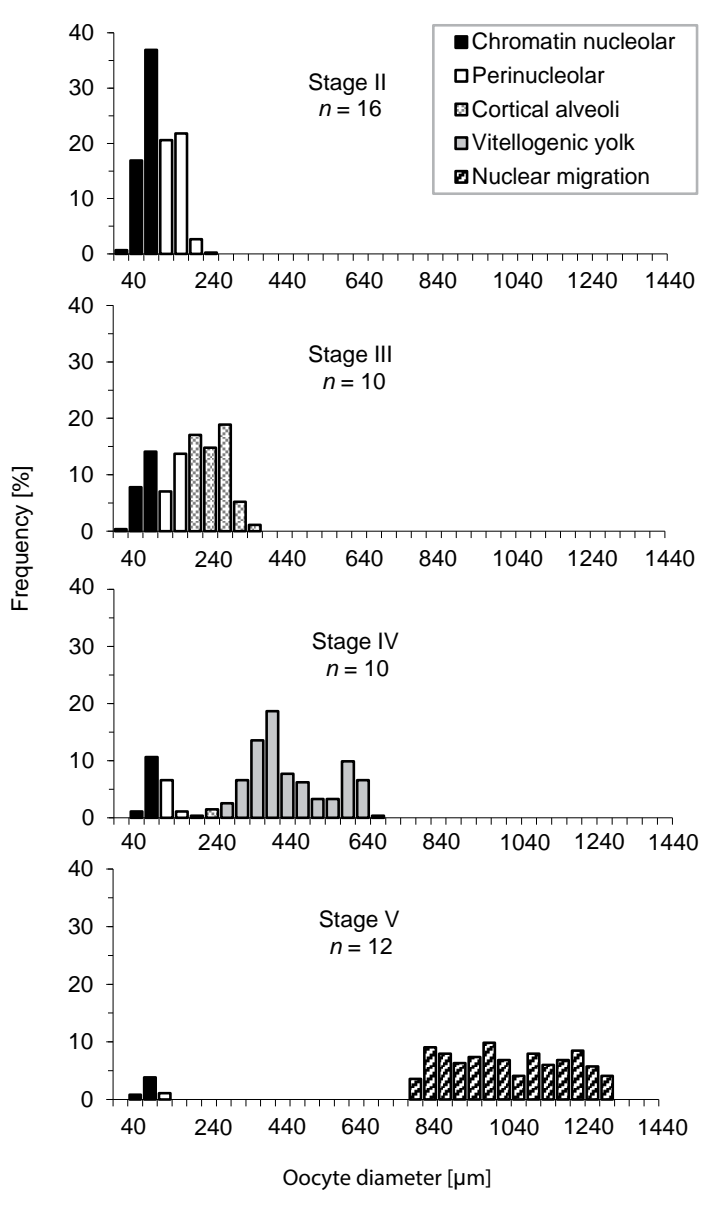

Fig. 5. Size-frequency distributions of oocytes diameters at each maturity stage of gonad development of pike (Esox lucius) collected from the Anzali Wetland (southwest Caspian Sea) from July 2012 through June 2013, the 4 maturity stages are previtellgenic: stage II, early vitellogenic: stage III, late vitellogenic: stage IV, final oocyte maturation: stage $\mathrm{V}(n=$ number of fish $)$

determination compared with linear regression in the mentioned relations.

Comparison of length-at-maturity curves showed a clear difference between males and females, with $L_{50}$ equal to 28.5 $\mathrm{cm}$ FL for males and $33.9 \mathrm{~cm}$ FL for females (Fig. 9). All males and females were mature at 34 and $41 \mathrm{~cm}$, respectively. Males and females below 24 and $28 \mathrm{~cm}$ were immature.

\section{DISCUSSION}

Gonadal development, spawning season, and reproductive strategy. The presence of two types of oocytes in ovaries classified as stage $\mathrm{V}$ suggested that pike have group synchronous pattern in gonad development like the majority of teleost fishes (Kunz-Ramsay 2004). Histological examination of gonads and size-frequency distribution of oocytes showed two batches of oocytes; a large group of advanced oocytes, which participate in spawning and a small group of growing oocytes with small size $(<0.2 \mathrm{~mm})$ that would be released over the next spawning season. Therefore, pike displayed a group synchronous pattern in oocyte development, similar to

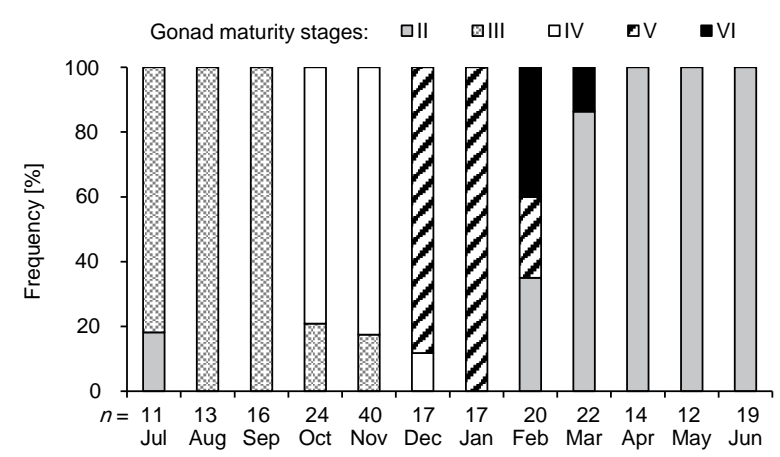

Fig. 6. Monthly distributions of females in the 5 stages of gonad maturity of pike (Esox lucius) collected from the Anzali Wetland (southwest Caspian Sea) from July 2012 through June ( $n=$ sample size)

Geru et al. (2012) and Lebeau (1991). Considering the majority of stage IV (late vitellogenesis) in November and the highest proportion of stage $\mathrm{V}$ (final oocyte maturation) in December and January, spawning could begin in February by developing toward and passing through stage V. Although the greatest amount of stage VI (spent females) were observed in February, their presence in March suggests that duration of spawning could last from February through March in the Anzali Wetland.

Furthermore, the relatively short spawning period (February to March), the lack of mature females with vitellogenic oocytes toward the end of the spawning season, and the presence of POFs confirmed that the spawning pattern is total. In total spawners, GSI is usually high just prior to spawning if this species shed all the oocytes that they will mature in that spawning season over a short time interval (Wootton 1998). In the presently reported study, GSI values of mature fish followed a similar pattern for both sexes and reached a maximum in January. The observed maximum GSI just prior to spawning (January), supports the spawning period described from the study of oocyte pattern. The spawning period may be linked to a gradual increase in water temperature from $7^{\circ} \mathrm{C}$ in February to $10^{\circ} \mathrm{C}$ in March in the Anzali Wetland. In many fish species, GSI along with the proportion of different reproductive stages has been proposed as a reliable technique to estimate the spawning period and the peak of spawning activity (Brown-Peterson et al. 2001, Lowerre-Barbieri et al. 2011).

Maximum and minimum HSI values were observed respectively in March and September. This suggests that pike store energy in the liver after using it for gonad development. This phenomenon has also been reported in cyprinid fishes by Mackay and Mann (1969). The HSI represents the amount of energy allocated to reproductive activities (Yaragina and Marshall 2000), so that the lesser variation of HSI in males compared with females could indicate less energy expenditure in the male reproductive cycle. Such a trend has been reported in Perca fluviatilis Linnaeus, 1758 (see Le Cren 1951, Craig 1977).

Reproduction of temperate-climate fishes is highly influenced by temperature (Bye 1984, Van Der Kraak and Pankhurst 1996) and the pike seems to be no exception, so 
that water temperature can influence the timing of spawning period (Wootton 1982, Lam 1983). As latitude decreases, the spawning season of pike populations starts earlier in the year. This is supported by the analysis of different thermal regimes, which vary from the cooler regions in the lakes of Scotland $\left(57^{\circ} \mathrm{N}\right)$ and Lithuania $\left(55^{\circ} \mathrm{N}\right)$, through warmer regions (a lake in Turkey; $38^{\circ} \mathrm{N}$ ) and south-western Caspian
Sea $\left(37^{\circ} \mathrm{N}\right)$ (Table 2$)$. A particular aspect of the influence of temperature is its role as a cue to trigger reproductive activity, and due to temperature effect on the vitellogenesis, low water temperature can cause delay in spawning time (Kjesbu 1994). This has been reported for other species (Morato et al. 2003, Saemi Komsari et al. 2013), and may occur in other pike populations.
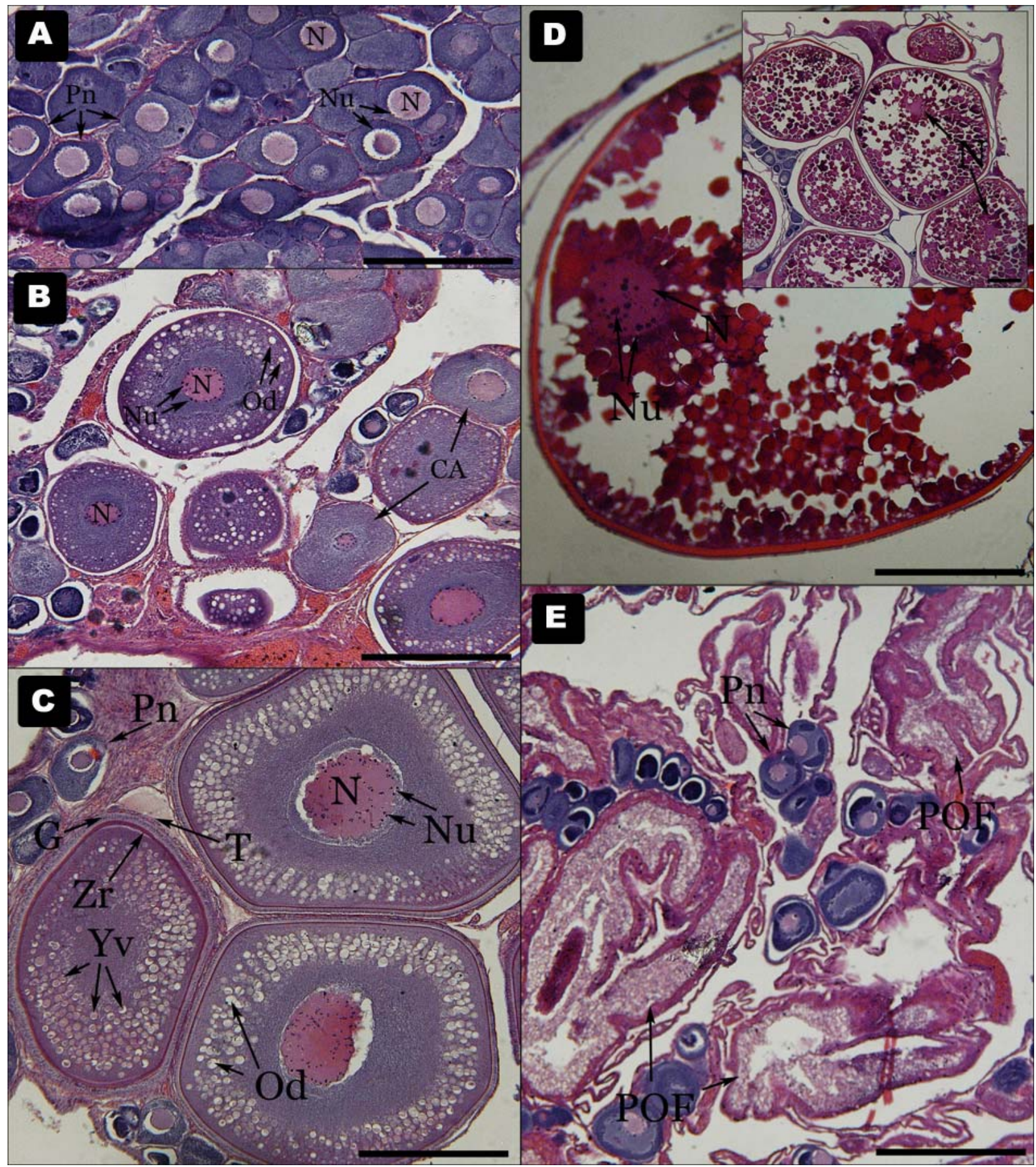

Fig. 7. Micrographs of transverse sections of ovaries of pike (Esox lucius) collected from the Anzali Wetland (southwest Caspian Sea) from July 2012 through June 2013; The final 5 stage of ovary development are shown: Stage II: previttelogenic (A), Stage III: early vitellogenic (B), Stage IV: late vitellogenic (C), Stage V: final oocyte maturation (D), and Stage VI: Spent $(\mathbf{E}) ; \mathrm{N}=$ nucleus, $\mathrm{Nu}=$ nuclei, $\mathrm{Pn}=$ perinucleolar, $\mathrm{CA}=$ cortical alveoli, $\mathrm{Od}=$ oil droplet, $\mathrm{Yv}=$ yolk vesicle, $\mathrm{T}$ $=$ thecal cell, $\mathrm{G}=$ granulosa cell, $\mathrm{Zr}=$ zona radiata layer, $\mathrm{POF}=$ postovulatory follicle; Scale bars: $300 \mu \mathrm{m}$ 

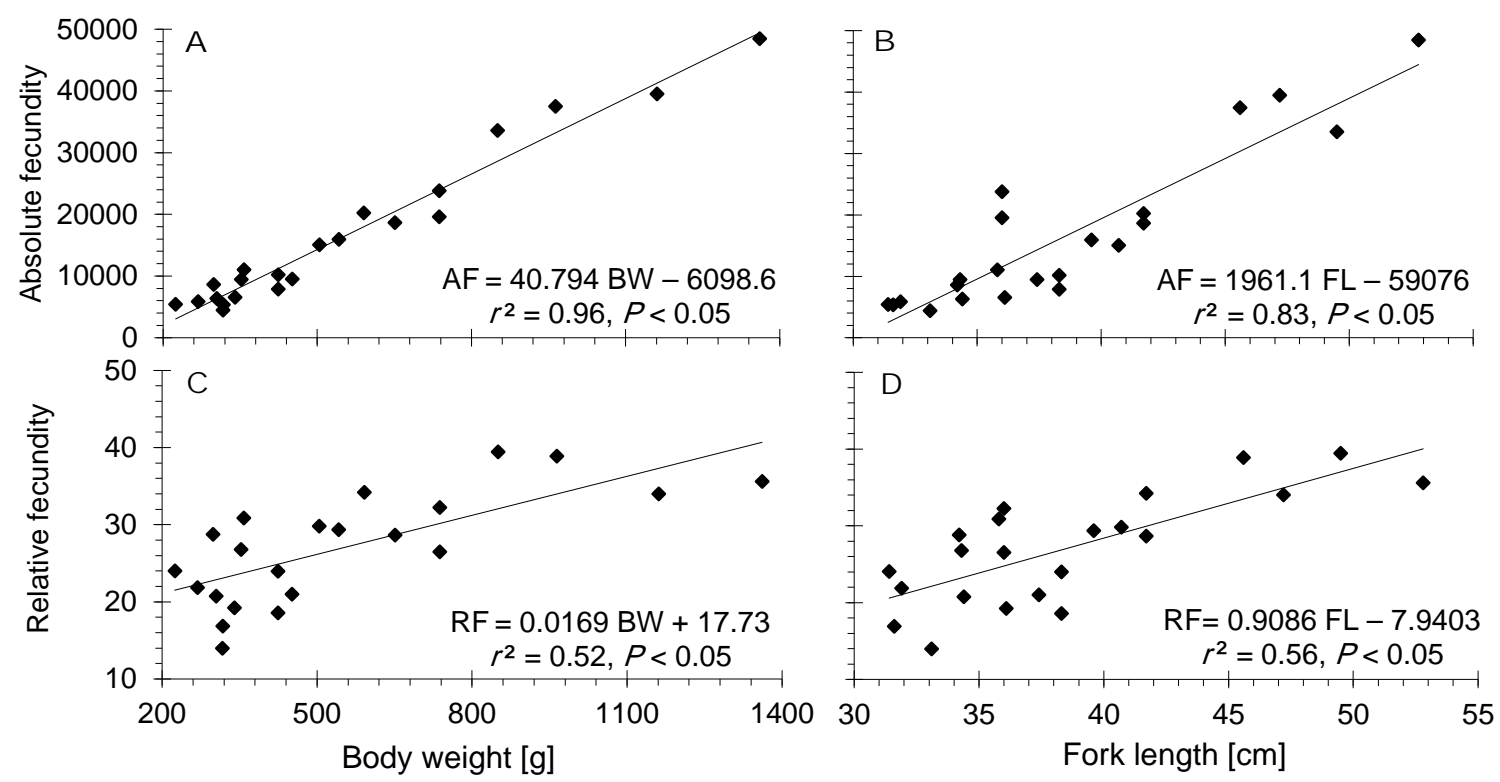

Fig. 8. Biometric relations of pike (Esox lucius) collected from the Anzali Wetland (southwest Caspian Sea) from 2012 through June 2013; Relation between absolute fecundity and body weight (A), Relation between absolute fecundity and fork length (B), Relation between relative fecundity and body weight (C), Relation between relative fecundity and fork length (D) $\left(r^{2}=\right.$ coefficient of determination)

Fecundity and length-at-maturity. Group synchronous pattern suggests a determinate fecundity (Render et al. 1995) for pike. The mean $F_{\mathrm{A}}$ in the presently reported study area was 16481 eggs (range: 4423-48471), which is similar to the result of $F_{\mathrm{A}}$ for pike in Karamık Lake $\left(38^{\circ} \mathrm{N}\right)$ with 2033-29050 eggs (Balık et al. 2006) and Kapulukaya dam lake $\left(39^{\circ} \mathrm{N}\right)$ with (mean \pm standard deviation) $19871.7 \pm$ 15051.1 eggs (Benzer et al. 2010). Lenhardt and Cakić (2002) estimated that the value of $F_{\mathrm{R}}$ was $40.4 \pm 12.5$ eggs per gram $W_{\mathrm{T}}$ in the Danube River $\left(44^{\circ} \mathrm{N}\right)$, while this value ranged between 15.1-41.6 eggs per gram $W_{\mathrm{T}}$ in the presently reported study $\left(37^{\circ} \mathrm{N}\right)$. Absolute and relative fecundity for pike revealed a positive relation between the number of oocytes and fish length and weight which is similar to those obtained by Mann (1976) and Benzer et al. (2010); therefore larger females have a higher contribution to egg production than smaller ones.

Finally, sizes-at-maturity in this study $\left(37^{\circ} \mathrm{N}\right)$ (males: $28.5 \mathrm{~cm}$ FL; females: $33.9 \mathrm{~cm}$ FL) were similar to those in Lake Rubikiai $\left(55^{\circ} \mathrm{N}\right)$, (26.8 FL cm for males and 33.4 FL cm for females; Žiliukienè and Žiliukas 2012), and Lake Karamık $\left(38^{\circ} \mathrm{N}\right)(27.9 \mathrm{~cm}$ FL for males and $29.1 \mathrm{~cm}$ FL for females; Balık et al. 2006). In contrast, sizes-at-maturity were larger in Windermere $\left(54^{\circ} \mathrm{N}\right)(35.8$ $\mathrm{cm}$ FL for males and $39.6 \mathrm{~cm}$ FL for females; Frost and Kipling 1967). These variations in $L_{50}$ could be related to environmental and anthropogenic factors such as temperature, food availability and fishing pressure (Roff 1992, Trippel et al. 1997).

Conclusions. Pike is a target species of commercial fisheries in the Anzali Wetland. The rise of its economic value has led to an increase of the captures in this area. The lack of information about its reproduction on the southwest cost of Caspian Sea has rendered fishery management difficult. The results of our study improve the current understanding of the reproductive dynamic of this species. From a morphological point of view, the structure and the development of ovaries do not differ from the development of gonads in other regions, although pike presents variation in its spawning season, a variation that is linked to its geographical distribution. Spatial variation in the reproductive features indicates that reproductive performances vary among geographical regions. Furthermore, the study of pike reproductive

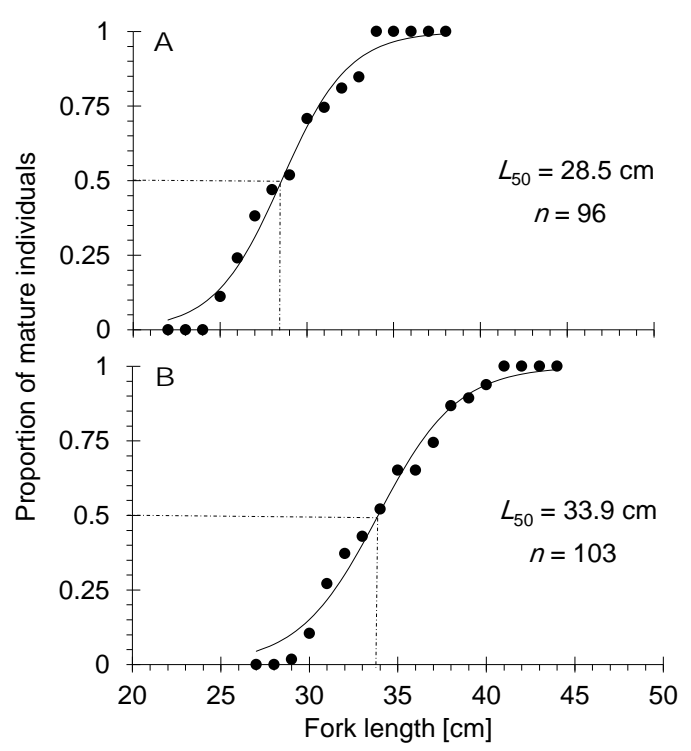

Fig. 9. Maturity ogives used to estimate length at maturity $\left(L_{50}\right)$ for male (A) and female (B) pike (Esox lucius) collected from the Anzali Wetland (southwest Caspian Sea) from July 2012 through June 2013, ( $n=$ sample size) 
Table 2

Spawning season of pike, Esox lucius at different latitudes

\begin{tabular}{|c|c|c|c|c|}
\hline Location & $\begin{array}{l}\text { Latitude } \\
{\left[{ }^{\circ} \mathrm{N}\right]}\end{array}$ & Spawning time & $\begin{array}{c}\text { Temperature } \\
{\left[{ }^{\circ} \mathrm{C}\right]}\end{array}$ & Reference \\
\hline Anzali Wetland, SW Caspian Sea & 37 & Feb-Mar & $7-10$ & Presently reported study \\
\hline Lake Karamık, Turkey & 38 & Feb-Mar & $4-8$ & Balık et al. 2006 \\
\hline Danube River, Belgrade & 44 & Feb-Apr & $5.5-9.8$ & Lenhardt and Cakić 2002 \\
\hline Torviscosa, Italy & 45.5 & Late Mar-end of May & - & Avian et al. 1998 \\
\hline Kleiner Döllnsee, Germany & 53 & Mar-mid-Apr & $5-8$ & Pagel 2009 \\
\hline Lake Rubikiai, Lithuania & 55 & Mar-April & 4 & Žiliukienė and Žiliukas 2012 \\
\hline Kinord and Davan Lakes, Scotland & 57 & First half of April & - & Treasurer 1990 \\
\hline Swedish coast of the Baltic Sea & Above 56 & $\begin{array}{l}\text { Last week of April in streams } \\
\text { First week of May in brackish } \\
\text { waters }\end{array}$ & - & Nilsson 2006 \\
\hline
\end{tabular}

characteristics in warmer region may help to visualize how climate change may affect its reproduction in northern areas. This may also bear some relevance to the management of pike populations known to have been introduced to higher latitude regions.

Males and females reach $L_{50}$ at 28.5 and $33.9 \mathrm{~cm}$ FL, respectively. As a consequence, the large catch and retention of individuals below the $L_{50}(29 \%$ of males and $68 \%$ of females landed) indicate that overfishing of this species could be a concern in the southwest of the Caspian Sea. If indiscriminate harvesting occurs, the number of fish that reach maturity could be reduced to such an extent that the reproductive capacity of the population would be diminished. One way of mitigating this risk is to ensure that minimal fishing pressure applied to the populations before the fish reach maturity. In addition, considering the spawning season (February and March), seasonal closure can be designed to protect key life stages. On balance, this study provides new data that are needed for a better understanding of the biology and ecology of pike; this knowledge will be useful in assessment and management of the stock that is exploited by the fisheries of southwest of the Caspian Sea.

\section{ACKNOWLEDGMENTS}

We would like to thank Mehrdad Sanjideh, Abouzar Habibi, and Farhad Borna for their collaboration during sampling. Special thanks go to Fatemeh Yektadoost and Morteza Masoudi for their assistance with histological analysis and laboratory works. Thanks are also due to Majid Mosapour and the Inland Water Aquaculture Research Institute staff (Bandar-e-Anzali) especially Mohammad Reza Nahrevar for their support.

\section{REFERENCES}

Abdoli A., Naderi M. 1999. [Iranian inland-water fishes.] Naghshe-Mana Press, Isfahan, Iran. [In Persian.]

Avian M., Specchi M., Vanzo S., Antonel P., Pizzul E. 1998. Biology of pike, Esox lucius (Esocidae), in the lower plain of Friuli-Venezia Giulia (north-eastern Italy). Italian Journal of Zoology 65 (S1): 247-250. DOI: $10.1080 / 11250009809386826$
Balık I., Çubuk H., Özkök R., Uysal R. 2006. Reproduction properties of pike (Esox lucius L., 1758) population in Lake Karamık (Afyonkarahisar/Turkey). Turkish Journal of Zoology 30 (1): 27-34.

Bani A., Moltschaniwskyj N.A. 2008. Spatio-temporal variability in reproductive ecology of sand flathead, Platycephalus bassensis, in three Tasmanian inshore habitats: Potential implications for management. Journal of Applied Ichthyology 24 (5): 555-561. DOI: $10.1111 /$ j.1439-0426.2008.01076.x

Benzer S., Gül A., Yilmaz M. 2010. Breeding properties of Esox lucius (L., 1758) living in Kapulukaya Dam Lake (Kirikkale, Turkey). African Journal of Biotechnology 9 (34): 5560-5565.

DOI: 10.5897/AJB09.1785

Bregazzi P., Kennedy C. 1980. The biology of pike, Esox lucius L., in a southern eutrophic lake. Journal of Fish Biology 17 (1): 91-112.

DOI: 10.1111/j.1095-8649.1980.tb02745.x

Brown-Peterson N.J., Overstreet R.M., Lotz J.M., Franks J.S., Burns K.M. 2001. Reproductive biology of cobia, Rachycentron canadum, from coastal waters of the southern United States. Fishery Bulletin 99 (1): 15-28.

Brown-Peterson N.J., Wyanski D.M., Saborido-Rey F., Macewicz B.J., Lowerre-Barbieri S.K. 2011. A standardized terminology for describing reproductive development in fishes. Marine and Coastal Fisheries 3 (1): 52-70.

DOI: $10.1080 / 19425120.2011 .555724$

Bye V.J. 1984. The role of environmental factors in the timing of reproductive cycles. Pp. 187-205. In: Potts G.W., Wootton R.J. (eds.) Fish reproduction: Strategies and tactics. Academic Press, London, UK.

Colmenero A.I., Tuset V.M., Recasens L., Sánchez P. 2013. Reproductive biology of black anglerfish (Lophius budegassa) in the northwestern Mediterranean Sea. Fishery Bulletin 111 (4): 390-401.

DOI: $10.7755 / F B .111 .4 .8$

Craig J. 1977. The body composition of adult perch, Perca fluviatilis in Windermere, with reference to seasonal changes and reproduction. Journal of Animal Ecology 46 (2): 617-632.

DOI: $10.2307 / 3834$ 
Craig J. (ed.) 1996. Pike: Biology and exploitation. Fish and Fisheries series 19, Chapman and Hall, London, UK. DOI: $10.1007 / 978-94-015-8775-4$

Davis T., West G.J. 1993. Maturation, reproductive seasonality, fecundity, and spawning frequency in Lutjanus vittus (Quoy and Gaimard) from the north west shelf of Australia. Fishery Bulletin 91 (2): 224 236.

Duarte R., Azevedo M., Landa J., Pereda P. 2001. Reproduction of anglerfish (Lophius budegassa Spinola and Lophius piscatorius Linnaeus) from the Atlantic Iberian coast. Fisheries Research 51 (2): 349361.

DOI: 10.1016/S0165-7836(01)00259-4

Einum S., Fleming I.A., Cote I.M., Reynolds J.D. 2003. Population stability in salmon: Species effect of population size and female reproductive allocation. Journal of Animal Ecology 72 (5): 811-821. DOI: 10.1046/j.1365-2656.2003.00752.x

Ewing G.P., Lyle J.M. 2009. Reproductive dynamics of redbait, Emmelichthys nitidus (Emmelichthyidae), from south-eastern Australia. Fisheries Research 97 (3): 206-215.

DOI: 10.1016/j.fishres.2009.02.007

Frost W.E., Kipling C. 1967. A study of reproduction, early life, weight-length relationship and growth of pike, Esox lucius L., in Windermere. Journal of Animal Ecology 36 (3): 651-693.

DOI: $10.2307 / 2820$

Ganias K., Somarakis S., Machias A., Theodorou A. 2004. Pattern of oocyte development and batch fecundity in the Mediterranean sardine. Fisheries Research 67 (1): 13-23.

DOI: 10.1016/j.fishres.2003.08.008

Geru L., Trofimov A., Ruxanda F., Rus V., Radu I., Pop R., Miclăuş V. 2012. Ovarian morphology of pike (Esox lucius) from the Danube River, during the oogenesis cycle. Annals of the Romanian Society for Cell Biology 17 (1): 307-311.

Glasser F., Mikolajczyk T., Jalabert B., Baroiller J.F., Breton B. 2004. Temperature effects along the reproductive axis during spawning induction of grass carp (Ctenopharyngodon idella). General and Comparative Endocrinology 136 (2): 171-179.

DOI: 10.1016/j.ygcen.2003.12.009

Hargalani F.Z., Karbassi A., Monavari S.M., Azar P.A. 2014. A novel pollution index based on the bioavailability of elements: a study on Anzali wetland bed sediments. Environmental Monitoring and Assessment 186 (4): 2329-2348.

DOI: $10.1007 / \mathrm{s} 10661-013-3541-4$

Hunter J.R., Macewicz B.J. 1985. Measurement of spawning frequency in multiple spawning fishes. NOAA Technical Report NMFS 36: 79-94.

Jakobsen T., Fogarty M.J., Megrey B.A., Moksness E. (eds.) 2009. Fish reproductive biology: Implications for assessment and management. Wiley-Blackwell, Oxford, UK.

DOI: $10.1002 / 9781444312133$
King M. 1995. Fisheries biology, assessment and management. Fishing News Books, Blackwell Science, Oxford, UK.

Kjesbu O. 1994. Time of start of spawning in Atlantic cod (Gadus morhua) females in relation to vitellogenic oocyte diameter, temperature, fish length and condition. Journal of Fish Biology 45 (5): 719-735.

DOI: $10.1111 /$ j.1095-8649.1994.tb00939.x

Kunz-Ramsay Y. 2004. Developmental biology of teleost fishes. Fish and Fisheries Series 28, Springer, Dordrecht, the Netherlands. DOI: 10.1007/978-1-4020-2997-4

Lam T. 1983. Environmental influences of gonadal activity. Pp. 1-65. In: Hoar W.S., Randall D.J. (eds.) Fish physiology. Vol. 9B. Academic Press, Orlando, FL, USA.

Lappalainen A., Härmä M., Kuningas S., Urho L. 2008. Reproduction of pike (Esox lucius) in reed belt shores of the SW coast of Finland, Baltic Sea: A new survey approach. Boreal Environmental Research 13 (4): 370-380.

Lebeau B. 1991. Oocyte recruitment and spawning chronology in pike, Esox lucius, and muskellunge, Esox masquinongy. Canadian Journal of Zoology 69 (8): 2194-2201.

DOI: $10.1139 / \mathrm{z} 91-306$

Le Cren E. 1951. The length-weight relationship and seasonal cycle in gonad weight and condition in the perch (Perca fluviatilis). Journal of Animal Ecology 20 (2): 201-219. DOI: $10.2307 / 1540$

Lenhardt M., Cakić P. 2002. Seasonal reproductive cycle of pike, Esox lucius L., from the River Danube. Journal of Applied Ichthyology 18 (1): 7-13. DOI: 10.1046/j.1439-0426.2002.00285.x

Lowerre-Barbieri S.K., Ganias K., Saborido-Rey F., Murua H., Hunter J.R. 2011. Reproductive timing in marine fishes: Variability, temporal scales, and methods. Marine and Coastal Fisheries 3 (1): 71-91. DOI: $10.1080 / 19425120.2011 .556932$

Mackay I., Mann K. 1969. Fecundity of two cyprinid fishes in the River Thames, Reading, England. Journal of the Fisheries Research Board of Canada 26 (11): 2795-2805.

DOI: $10.1139 /$ f69-276

Mann R.H.K. 1976. Observation on the age, growth, reproduction and food of the pike Esox lucius (L.) in two rivers in southern England. Journal of Fish Biology 8 (2): 179-197.

DOI: $10.1111 /$ j.1095-8649.1976.tb03930.x

Marshall C.T., Kjesbu O.S., Yaragina N.A., Solemdal P., Ulltang Ø. 1998. Is spawner biomass a sensitive measure of the reproductive and recruitment potential of Northeast Arctic cod? Canadian Journal of Fisheries and Aquatic Sciences 55 (7): 1766-1783.

DOI: $10.1139 / \mathrm{f} 98-062$

Morato T., Afonso P., Lourinho P., Nash R.D.M., Santos R.S. 2003. Reproductive biology and recruitment of 
the white sea bream in the Azores. Journal of Fish Biology 63 (1): 59-72.

DOI: $10.1046 /$ j.1095-8649.2003.00129.x

Morgan M.J. 2008. Integrating reproductive biology into scientific advice for fisheries management. Journal of Northwest Atlantic Fishery Science 41: 37-51.

DOI: $10.2960 /$ J.v41.m615

Moslemi-Aqdam M., Imanpour Namin J., Sattari M., Abdolmalaki Sh., Bani A. 2014. Length-length, length-weight relationship and relative condition factor of pike, Esox lucius Linnaeus, 1758, in Anzali Wetland (Southwest of the Caspian Sea). Caspian Journal of Environmental Science 12 (1): 109-117.

Murua H., Saborido-Rey F. 2003. Female reproductive strategies of marine fish species of the North Atlantic. Journal of Northwest Atlantic Fishery Science 33: 23-31.

Nilsson J. 2006. Predation of northern pike (Esox lucius L.) eggs: a possible cause of regionally poor recruitment in the Baltic Sea. Hydrobiologia 553 (1): 161-169.

DOI: $10.1107 / \mathrm{s} 10750-005-1949-8$

Render J.H., Thompson B.A., Allen R.L. 1995. Reproductive development of striped mullet in Louisiana estuarine waters with notes on the applicability of reproductive assessment methods for isochronal species. Transactions of the American Fisheries Society 124 (1): 26-36.

DOI: $10.1577 / 1548-8659(1995) 124<0026$ :RDOSMI $>2.3 . C O ; 2$

Roff D.A. 1992. The evolution of life histories: Theory and analysis. Chapman and Hall, New York, NY, USA.

Saemi Komsari M., Bani A., Khara H., Reza Esmaeili H. 2013. Reproductive strategy of the European perch, Perca fluviatilis Linnaeus, 1758 (Osteichthyes: Percidae) in the Anzali wetland, southwest Caspian Sea. Journal of Applied Ichthyology 30 (2): 307-313. DOI: $10.1111 /$ jai.12335

Salcedo-Bojorquez S., Arreguin-Sanchez F. 2011. An exploratory analysis to identify reproductive strategies of billfishes. Journal of Fisheries and Aquatic Science 6 (6): 578-591.

DOI: $10.3923 /$ jfas.2011.578.591

Sattari M., Shahsavani D., Shafei S.H. 2002. [Systematic Ichthyology.] Haghshenas Press, Rasht, Iran. [In Persian.]

Silva A., Santos M.B., Caneco B., Pestana G., Porteiro C., Carrera P., Stratoudakis Y. 2006. Temporal and geographic variability of sardine maturity at length in the northeastern Atlantic and the western Mediterranean. ICES Journal of Marine Science 63 (4): 663-676.

DOI: $10.1016 /$ j.icesjms.2006.01.005

Thulasitha W.S., Sivashanthini K. 2013. Reproductive characteristics of doublespotted queenfish, Scomberoides lysan (Actinopterygii: Perciformes: Carangidae), from Sri Lankan waters: Implications for fisheries management. Acta Ichthyologica et Piscatoria 43 (1): 7-13.

DOI: $10.3750 / A I P 2013.43 .1 .02$
Treasurer J. 1990. The annual reproductive cycle of pike, Esox lucius L., in two Scottish lakes. Journal of Fish Biology 36 (1): 29-46.

DOI: $10.1111 /$ j.1095-8649.1990.tb03517.x

Trippel E.A., Kjesbu O.S., Solemdal P. 1997. Effects of adult age and size structure on reproductive output in marine fishes. Pp. 31-62. In: Chabmers R.C., Trippel E.A., (eds.) Early life history and recruitment in fish populations. Chapman and Hall, New York, NY, USA.

Van Der Kraak G., Pankhurst N.W. 1996. Temperature effects of the reproductive performance of fish. Pp. 159 176. In: McDonald G., Wood C.M. (eds.) Implications for Freshwater and Marine Fish. Cambridge University Press, Cambridge, UK.

Wallace R.A., Selman K. 1981. Cellular and dynamic aspects of oocyte growth in teleosts. American Zoology 21 (2): 325-343.

DOI: $10.1093 / \mathrm{icb} / 21.2 .325$

West G. 1990. Methods of assessing ovarian development in fishes: A review. Marine and Freshwater Research 41 (2): 199-222.

DOI: $10.1071 / \mathrm{MF} 9900199$

Wootton R.J. 1982. Environmental factors in Fish reproduction. Pp. 210-219. In: Richter C.J.J., Goss H.J.T. (eds.) Reproductive physiology of fish. Pudoc, Wageningen, the Netherlands.

Wootton R.J. 1998. Ecology of teleost fishes. 2nd ed. Kluwer, London, UK.

Yamamoto K. 1956. Studies on the formation of fish eggs. Annual cycle in the development of ovarian eggs in the flounder, Liopsetta obscura. Journal of the Faculty of Science, Hokkaido University, Ser 6, Zoology 12 (3): 362-373.

Yamamoto Y., Shiah F.K. 2012. Spatial variation in the spawning season of bluegill Lepomis macrochirus in Lake Biwa, Japan. Zoological Studies 51 (8): 14461453.

DOI: $10.1186 / 1810-522 \mathrm{X}-52-19$

Yaragina N., Marshall C. 2000. Trophic influences on interannual and seasonal variation in the liver condition index of Northeast Arctic cod (Gadus morhua). ICES Journal of Marine Science 57 (1): 42-55. DOI: $10.1006 /$ jmsc. 1999.0493

Ziegler P.E., Lyle J.M., Haddon M., Ewing G.P. 2007. Rapid changes in life history characteristics of a longlived temperate reef fish. Marine and Freshwater Research 58 (12): 1096-1107.

DOI: $10.1071 / \mathrm{MF} 07137$

Žiliukienė V., Žiliukas V. 2012. Spawning population characteristics of pike Esox lucius L. in Lake Rubikiai (Lithuania). Central European Journal of Biology 7 (5): $867-877$.

DOI: $10.2478 / \mathrm{s} 11535-012-0073-9$

Received: 4 March 2016

Accepted: 13 November 2016

Published electronically: 31 December 2016 